\title{
大型振動台基礎側面に作用する地震時土圧の観測と解析 \\ OBSERVATION AND ANALYSIS OF SEISMIC EARTH PRESSURES ON THE SIDES OF A LARGE-SCALE SHAKING-TABLE FOUNDATION
}

\author{
井口道雄*1, 武藤 尊彦*2, 箕 輪 親 宏*3 \\ Michio IGUCHI, Takayoshi MUTOH and Chikahiro MINOWA
}

\begin{abstract}
The dynamic characteristics of earth pressures during earthquakes that have been observed on the lateral sides of an embedded large-scale-shaking-table foundation are studied. The observed results have shown that the earth pressures on the opposite sides of the foundation were generated in phase for relatively lower frequencies and tend to be out of phase for higher frequencies. It was also detected that the earth pressures on the lateral sides of the foundation were strongly related to the horizontal velocity motions of the foundation for relatively lower frequencies and to the acceleration motions for higher frequencies. The analyses for the earth pressures were conducted by use of a simple lumped-mass-system equivalently replaced for the lateral soil of two surface layers. Fairly good agreement between the analyses and the observed results was presented.
\end{abstract}

Keywords: Soil-structure interaction, Earthquake observation, Seismic Earth pressure,

Embedded foundation, Simulation analysis

動的相互作用、地震観測、地震時土压、埋込み基礎、シミュレーション解析

\section{1. はじめに}

構造物への地震動の入力伝達あるいは建物の振動に対する地盤抵 抗は、土圧の発生を伴って引き起こされる現象である。したがって、 基礎に作用する地震時土压を観測しその特性を明らかにすることは、 地震動の建物への入力機構さらには地盤の抵抗機構を明らかにする 上できわめて重要となる。

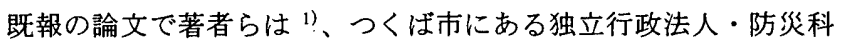
学技術研究所の大型振動台基礎について、強制加振時の基礎側面の 動土圧特性を明らかにするとともに、側方地盤を簡易な質点モデル に㯰換して行った理論計算結果と観測值を比較し、両者が良く対応 していることを示した。この振動台基礎については地震時変動土压

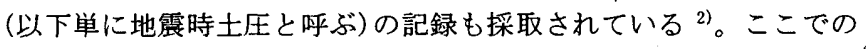
地震観測の一つの特徵は、相対する基礎両側面の地震時土圧が基礎 応答および周辺地盤での地震動と共に同時観測されている点である。 本論文ではこの振動台基礎側面で観測された地震時土圧を基に、そ の特性を明らかにするとともに、質点一ばねーダッシュポットを基 本とする簡易解析モデルを用いて得られる地震時土圧の計算結果と 比較照查した結果について述べる。

地震時土圧に関する検討は、これまでにも様々な手法によって行 われている。中でも実構造物基礎あるいは実地盤内に設置された模 型基礎に対する地震時土圧の観測は、実現象の把握という点から極 めて貴重なデー夕を提供している。また、観測記録を基に土圧の周
波数特性、基礎底面あるいは基礎側面の土圧分布性状、相対する基 礎側面での土圧の位相特性、さらには土圧が基礎の応答とどのよう に関わっているかに焦点を当てた土圧の発生機構に関する研究など、 様々な視点に立った実証的研究が発表されている列えば5) 11)。

これらの観測結果の中で特に注目されるのは、相対する基礎側面 には同位相の土圧が発生する場合がある、こと ${ }^{5)}$ ８)、また、地震時土 圧と基礎応答との関保については、基礎側面土圧は基礎の速度応答

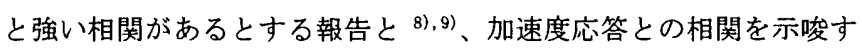
る報告 ${ }^{10)}$ があることであろう。とりわけ、基礎側面土圧が同位相で 発生する現象は、基礎に対する地震入力を評価する上で重要となる。 また、基礎側面の地震時士圧が基礎のどのような動きと対応して発 生するかを明らかにすることも、基礎に対する地盤抵抗モデルを作 成する上で重要となる。本論文でも、これらの現象に焦点を当てて 観測記録の分析を試みた。

\section{2. 振動台基礶・土圧計測の概要と地震記録の選択}

大型振動台基礎と基礎両側面の土圧計の配置を図 1(a)、(b)に示 す。この基礎の平面の大きさは、 $39 \times 25 \mathrm{~m}^{2}$ で $8.2 \mathrm{~m}$ の埋込みを有し、 締まった砂層に直接支持されている。また、基礎底面に到る厚さ 8 $\mathrm{m}$ の表層地盤は 2 層構造になっていて、第 1 層は厚さ $3 \mathrm{~m}$ 、第 2 層 は厚さ $5 \mathrm{~m}$ である（図 2 参照)。図 2 には地中 $-47 \mathrm{~m}$ までの地盤構造 と地盤物性が示してある ${ }^{1), 3) 。 ~}$
*1 東京理科大学理工学部建築学科 教授. 工博

*2 東京理科大学理工学部建築学科 助手·工修.

*3 独立行政法人防災科学技術研究所 流動研究員 $\cdot$ 工修
Prof., Dept. of Architectural Engineering, Faculty of Science and Engineering, Science Univ. of Tokyo, Dr. Eng.

Research Assoc., Dept. of Architectural Engineering, Faculty of Science and Engineering, Science Univ. of Tokyo, M. Eng.

Scientific Research Advisor, The National Research Institute for Earth Science and Disaster Prevention, M. Eng. 


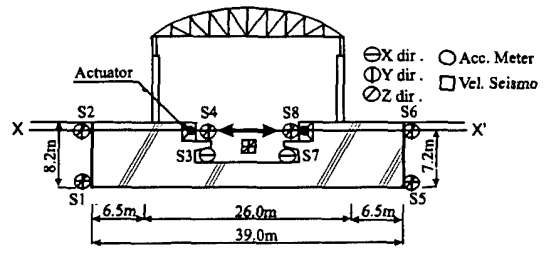

（a）基磖断面と地震計配置

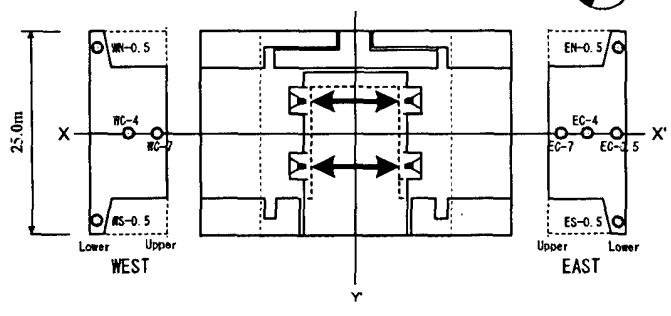

（b）基礶平面と土圧計正置

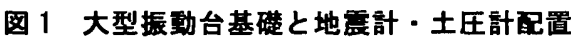

振動台基礎の地震観測は、図 1 (a)に示すように、基礎上に設置さ れた速度計と加速度計を用いて行われている。地震時の基䃈水平応 答は基礎のほほ中央に位置する観測点 S3 の記録で代表させること とした。また、自由地盤の地震動観測は、基礎中央から約 $100 \mathrm{~m}$ 離 れた地点の地中 $-40 \mathrm{~m}$ とー $1 \mathrm{~m}$ に埋設された加速度計によって行われ ている。以降、本論文では- $1 \mathrm{~m}$ の記録を地表記録と呼ぶことにする。

一方、図 1 (b)には土圧計配置が示してある。この図に示すように、 土圧計は東西両側面に基礎底面から $0.5 \mathrm{~m}, 4.0 \mathrm{~m}, 7.0 \mathrm{~m}$ の高さに設 置されている。地震時土圧の観測は 1991〜1996 年の 6 年間にわたっ て行われ、この間に合計 19 地震について基礎及び自由地盤での同時

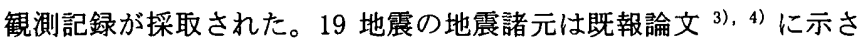
れている。これらの既論文では、地震動波形に含まれる周波数成分 と基礎有効入力動との関係を明らかにするために、地表での加速度 波形（NS 成分）に含まれる周波数成分に応じて地震記録を A, B， C の三つのグループに分類した。グループ A は $1 \mathrm{~Hz}$ 以下の比較的低振 動数成分を多く含む地震動、グループC は $3 \sim 4 \mathrm{~Hz}$ 以上の高振動数成 分を含むもの、グループ B は雨者の中間の性質を持つ地震動とする。 本論文では、これら各グループに属する地震記録から、地表での加 速度が最も大きい地震波またはそれに準ずる地震波を一つ選択し、 それらについて地震時土圧特性の分析とシミュレーション解析を行 った。表 1 には、選択した三つの地震記録の諸元が再録してある。 また、図 3 にはグループ毎の地表記録の正規化フーリェスペクトル が示してある。

\section{表 1 地震記録の諸元}

\begin{tabular}{|c|c|c|c|c|c|c|}
\hline $\begin{array}{c}\text { 地层 } \\
\text { 番号 }\end{array}$ & 発生日 & 発生場所 & $\begin{array}{c}\text { 深さ } \\
(\mathrm{km})\end{array}$ & $\begin{array}{c}\text { 規模 } \\
(\mathrm{M})\end{array}$ & $\begin{array}{c}\text { 地等記録の } \\
\text { 最大加速度 (gal) }\end{array}$ & タルーフ \\
\hline 3 & 1991.10 .19 & N36.08, E139.92 & 59 & 4.3 & 43.73 & $\mathrm{C}$ \\
\hline 17 & 1993.10 .12 & N32.02, E138.24 & 390 & 7.0 & 27.15 & $\mathrm{~B}$ \\
\hline 30 & 1996.9 .11 & N35.07, E141.03 & 30 & 6.6 & 26.65 & $\mathrm{~A}$ \\
\hline
\end{tabular}

\section{3. 地震時土压の钼測結果}

\section{1 基礎両側面土圧の位相特性}

図 4 (a)，(b)にはグループA の地震に対して、相対する基礎両側面 で観測された土圧波形と、両側面土圧を時刻毎に乗じたモーション プロダクトの時刻歷がそれぞれ示してある。同様にして、図 5 と図

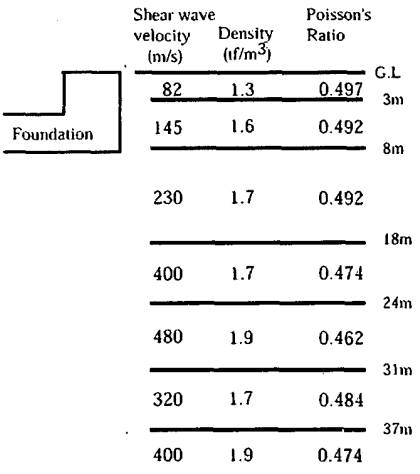

图 2 地盤の椥要 1)，3

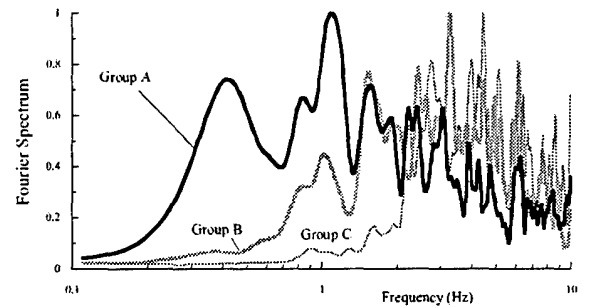

图 3 地震動の正規化フーリエスペクトル ${ }^{3)}$
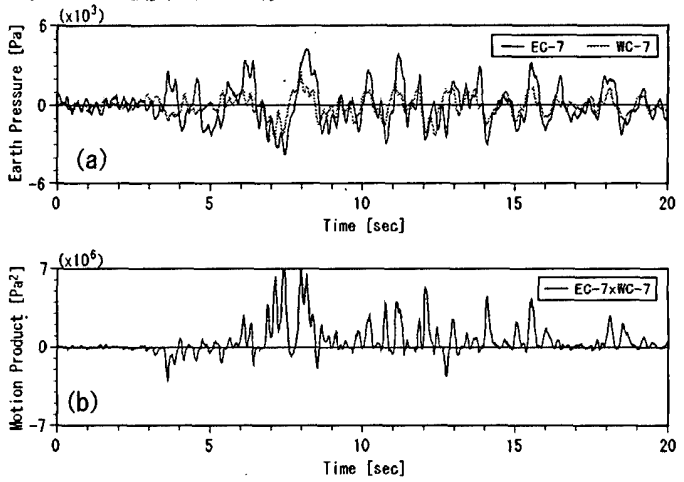

（a）基礎両㑡面の地震時土圧波形（b）モーションプロダクト 图 4 基礎両側面土压の位相関係 (Group A)
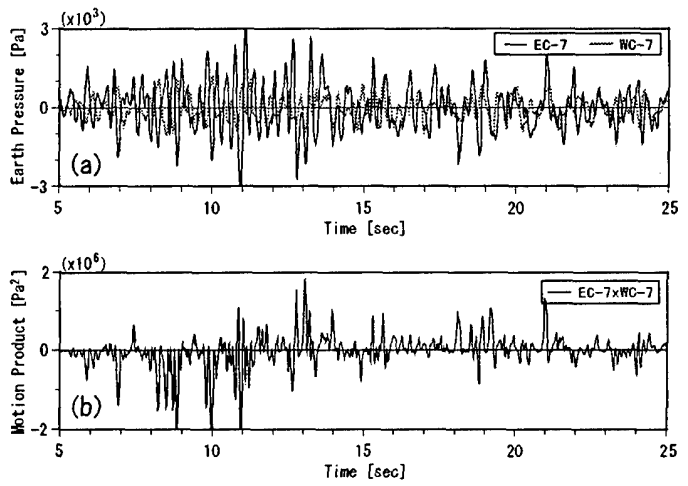

（a）基硽両側面の地震時土圧波形（b) モーションプロダクト 图 5 基礎両側面土圧の位相関係 (Group B)

6 はそれぞれグループ B，C の結果である。当然のことながら、モー ションプロダクトは基礎両側面の土庄が同位相であれば正側に、逆 位相で発生していれば負側に振れることになる。このことを踏まえ て図 4〜6を観察すれば以下のことが認められる。

（1）図 4 (a)の側面土圧波形、さらには(b)のモーションプロダク トに明瞭に現れているように、比較的低振動数成分を含むグループ A では、相対する基礎側面土圧の位相特性は、初期微動部分を除く 
ほほ全時間帯で同位相となっている。

（2）グループAよりやや高振動数成分を含むグループ B では、 図 5 (b)に見るように、初期微動の時間帯でモーションプロダクト は負側に振れ、両側面土圧が逆位相で発生しているが、約 12 秒付 近以降のやや低振動数成分を含む主要動部分では、両側面土圧は 同位相で発生しているのが認められる。

（3）図 6 に示すグループCでは、波形の後半部分で両側面土圧 が同位相で発生している部分があるが、全般的には負側に振れて いて両側面土圧が逆位相となっている時間帯が多い。また、主要 動部分ではモーションプロダクトは正負交互に振れ、位相特性に ついて明確な特徵は見出せない。

以上をまとめれば、相対する基礎側面に作用する地震時土圧は、 低振動数成分の地震動に対しては同位相で生じ、高振動数成分に 対しては逆位相となる傾向が認められ、位相特性は地震動に含ま れる振動数成分に強く影響されることがわかる。このような傾向 は、比較的小規模の埋め込み基礎に対する地震観測記録にも現れ ている ${ }^{6 ）}$ ，7)。基礎両側面の地震時土圧が同位相で発生するという ことは、相対する基礎側面からの地震入力は互いに相殺され、基 礎に対して有効な入力にならないことを意味している。この現象 は地震動の建物への入力機構を検討するうえで重要であり、他の 地盤あるいは基礎条件に対する地震時土圧の観測記録の蓄積が望 まれる。

\section{2 基硌応答と側面土压との関係}

地震時土圧に関してもう一つ重要なのは、側面土圧は基礎のど のような動きに対応して発生するかを明らかにすることである。 図 7 (a)，(b)，(c)には、グループ毎に基礎の速度応答波形と土圧波 形が同時に示してある。これらの結果より、低振動数成分を含む グループA とやや高振動数成分を含むグループ B では、基礎側面 の地震時土圧は基礎の速度応答と位相が対応しており, 両者間に は強い相関があることが伺われる。一方、高振動数成分が卓越す るグループCでは、基礎の速度応答と側面土圧との対応は殆ど認 められない。

図 8 (a)，(b)には、グループCについて地震時の基礎の加速度波 形と基礎側面土圧波形(EC-4) が同時に示してある。なお、加速度 波形には負号を乗じたものと比較してある。この図から明らかな ように、高振動数成分が卓越するグループCでは、基礎側面土圧 は基礎加速度応答と強い相関があるのが分かる。図には示してい ないが、グループ B の一部高振動数域で、基礎側面土圧と基礎の 加速度応答との明確な対応が認められた。

図 9 (a)〜 (e)にはグループ B の地震記録について、基礎速度に 対する各観測点の土圧の振幅スペクトル比が示してある。これら の結果はバンド幅 $0.2 \mathrm{~Hz}$ の Parzen Window で平滑化してある。ま た、図の縦軸の単位は、既報論文 ${ }^{1)}$ の加振実験時の土圧特性と対 比させるために、特に $\left[\mathrm{kgf} / \mathrm{cm}^{2} / \mathrm{cm} / \mathrm{sec}\right]$ としてある。図 9 を観察 すると、以下の事柄が考察される。

（1）基礎速度に対する基礎側方の地震時土圧は、 $4 \sim 5 \mathrm{~Hz}$ 程度ま ではほぼ一定または若干の增加傾向を示すが、それ以上の振動数 域では振動数の増加に伴って急激な増加傾向を示す。なお、基礎 側方地盤の固有振動数は $3.5 \mathrm{~Hz}$ と推定されている ${ }^{1)}$ 。結果は図示し ていないが、図 9 の傾向はグループ A, C についても同様の傾向が認
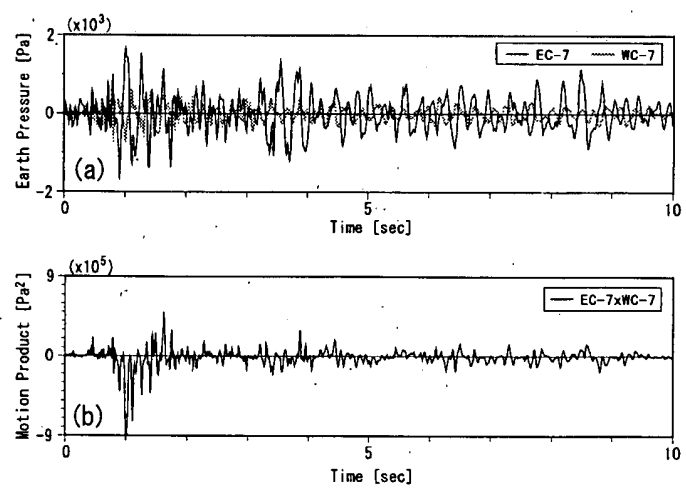

（a）基喏両㑡面の地震時土压波形（b）モーションプロダクト

图 6 基䃎両側面土压の位相関保 (Group C)

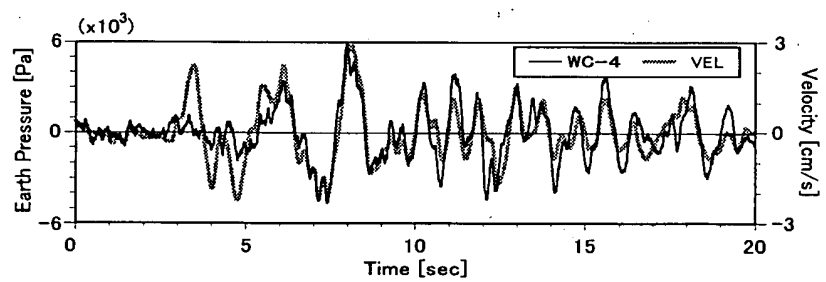

(a) Group A

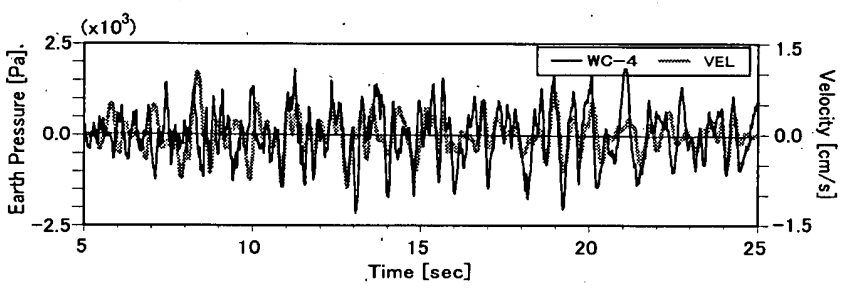

(b) Group B

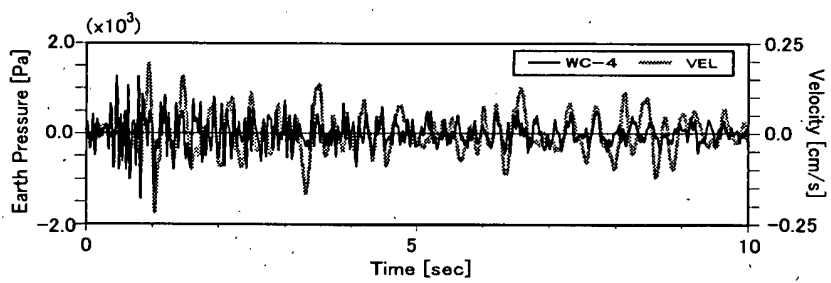

(c) Group C

图 7 基硌速度と㑡面土压の同時锶测波形
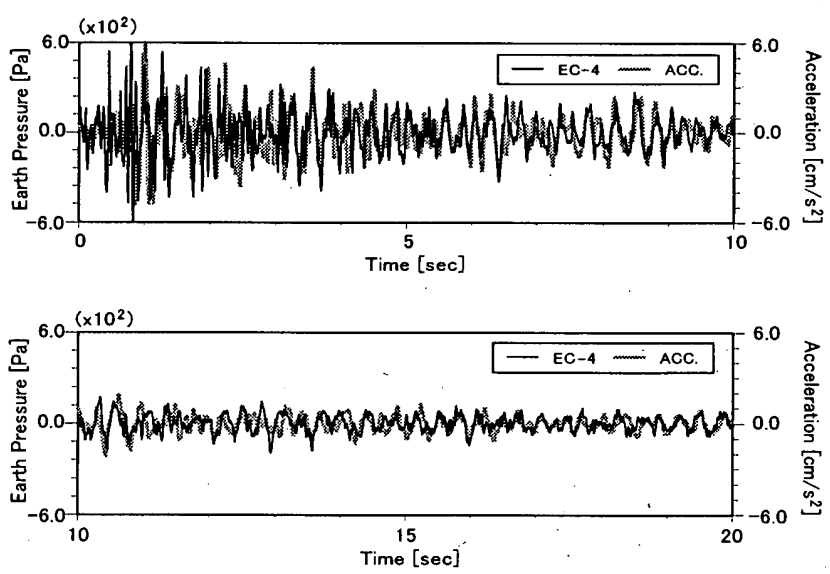

图 8 基碮加速度と側面土压の同時覞測波形(Group C) められた。

（2）上述の基脴側面土圧の周波数特性は、既報の論文 ${ }^{1)}$ に示した 基礎加振実験時における傾向と異なる。後述するように、地震時の 
側面土圧は基礎态答に抵抗 して発生する成分と、側方 地盤の地震動に対して基礎 側面に作用する成分とが複 合されたものとなる。した がって、前者の成分が優勢 であれば側面土圧は加振実 験時の特性と同じになるが、 後者の成分が強ければ土圧 性状は違った傾向となる。 この振動台基礎の場合には、 地震時土压には後者の影響 が強く現れていることが示 唆される。

\section{4. 地震時土压の解析}

\section{1. 解析モデルの作成}

上で述べた基礎側面の地震時土圧特性を解析によって検証する ために、図 2 に示す基礎一地盤系を質点・ばね・ダッシュポット を基本とする図 10 の簡易モデルに置換して解析する。すなわち、 この図に示すように、基礎を剛として基礎底面には下部地盤の動 的地盤抵抗を表現するスウェイ・ロッキングばねとダッシュポッ 卜を配し、さらに基礎側方地盤は並列する質点モデルに置換して、 基礎に対する側方地盤からの地震入力と基礎に対する地盤抵抗を 表現する。この並列質点モデルは、加振実験時の側方地盤抵抗を 表現するため、厚さ $8 \mathrm{~m}$ の表層 2 層地盤をそれと等価なモデルに 置換したもので、既報論文 ${ }^{1)}$ で用いたものと同一である。側方地 盤を並列質点モデルに置換するに当たっては、次の仮定を設けた。

（1）側方地盤については 2 次元平面ひずみ状態とし、水平変位 のみ考慮し上下変位の影響は小さく無視できるものとする。

（2）基䃈側方は 2 層の平行成層地盤とし、下方地盤は剛とする。

（3）地盤は弾性体とし、材料減衰は履歴型の複素減衰を仮定す る。ただし、第 1 層と 2 層の減衰定数 $h$ の值は同一とし、 $h=0.1$ とする。

以上の仮定の下で、基礎側方地盤の 1 次モードに対応する等価質 点系モデルとして図 10 の解析モデルを設定した。表 2 には質点モデ ルの諸定数が再録してある ${ }^{1}$ 。これらの数值のうち、等価質量、等 価せん断ばね定数、等価軸方向ばね定数は側方地盤の単位幅 $(1 \mathrm{~m})$ 当たりの值である。

相対する基礎側面の地震時土圧が同位相で生ずる現象は、内山・ 山下 ${ }^{7)}$ が指摘しているように、地震動の鉛直入射、すなわち基礎お よび各質点脚部に同位相・同振幅の地動が作用するとする想定では 説明できない。内山・山下 ${ }^{7)}$ は基礎側面の地震時土圧が同位相で発

\section{表 2 並列質点モデルの諸定数 ${ }^{1}$}

\begin{tabular}{|ll|}
\hline 刺激係数 & $\beta_{1}=1.41$ \\
等価質点高さ & $H^{e}=5.7[\mathrm{~m}]$ \\
質点間隔 & $\Delta x=1.0[\mathrm{~m}]$ \\
等価質量 & $M^{e}=0.92 \quad\left[t f \cdot \mathrm{sec}^{2} / \mathrm{m}^{2}\right]$ \\
等価せん断ばね定数 & ${ }_{s} K^{e}=(745.5+149.1 i)\left[t \mathrm{t} / \mathrm{m}^{2}\right]$ \\
等価軸方向ばね定数 & ${ }_{n} K^{e}=(10.9+2.18 i) \times 10^{5}\left[t \mathrm{f} / \mathrm{m}^{2}\right]$ \\
\hline
\end{tabular}
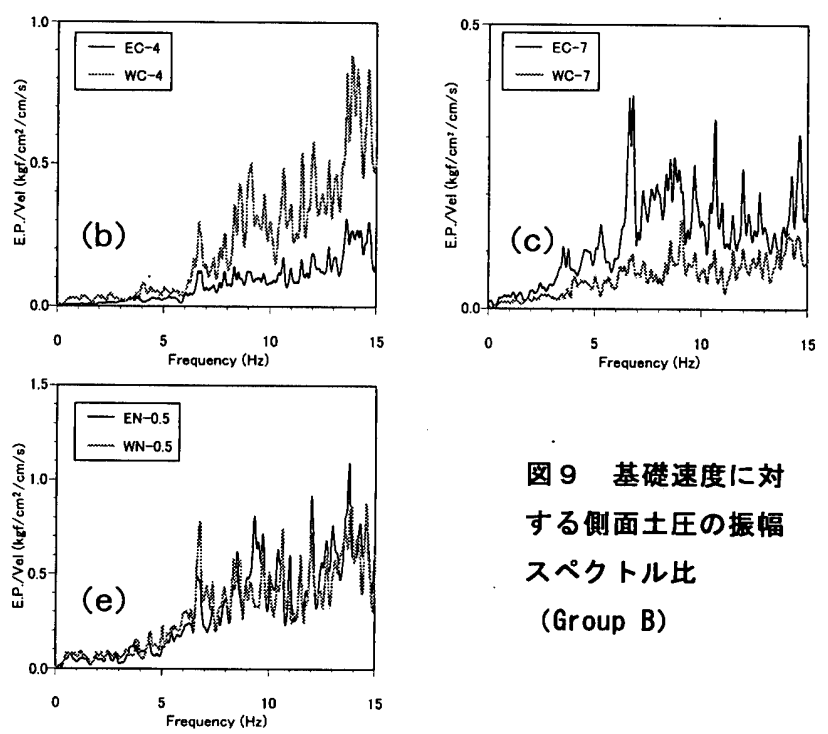

图 9 基礎速度に対 する側面土圧の振幅 スペクトル比 (Group B)

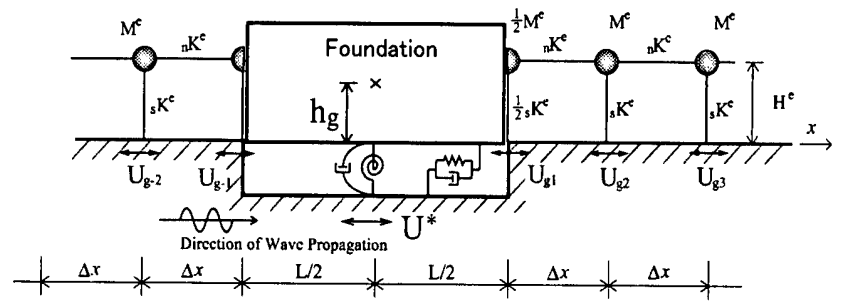

图 10 基礎一地盤系の質点モテル

(a) 右方地盤
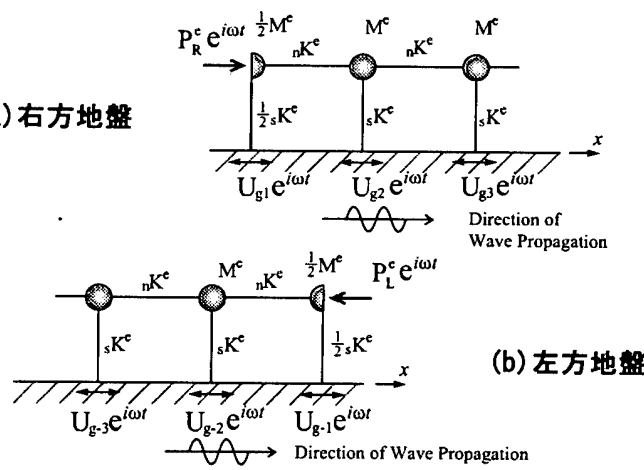

图.11基礎㑡方地盤の質点系モデル

生する現象を 2 次元 FEM を用いて解析しているが、本論文では図 10 の剛基礎一質点系モデルを用い、 $x$ 方向に伝播する地震動入力を想 定したときの基礎の応答と地震時土圧を解析し現象の解明を試みる。

\section{2 基礎側方地盤の解析}

図 10 に示すように基礎底面の中央を原点として $x$ 軸を定める。こ の剛基礎一質点系モデルに対する基礎の地震応答と地震時土圧を求 めるためには、図 $11(\mathrm{a})$ ，(b)に示す左右の側方地盤モデルにそれぞ れ $P_{L}^{e} e^{i \omega t}, P_{R}^{e} e^{i \omega t}$ の調和加振力と、 $x$ 方向に伝播寸る地震動が同時に作 用するときの質点の応答を求める必要がある。これらの解析のうち、 まず図 11 (a)の右方の側方地盤について考える。

端部質点に水平加振力 $P_{R}^{e} e^{i \omega t}$ のみが作用した時の質点 1 の変位応 答を $X_{1}^{(1)} e^{i \omega t}$ とする。この応答の解析解は既報の論文 ${ }^{1)}$ に与えられて いる。結果を改めて畫けば次のようになる。

$$
X_{1}^{(1)}=\frac{1}{{ }_{n} K^{e} \operatorname{Sh} \alpha} P_{R}^{e}
$$

ここで、 $\alpha$ は運動方程式を解く際に登場する特性方程式の解、Shは 
双曲線関数である。また、 ${ }_{n} K^{e} S h \alpha$ は側方地盤単位幅 $(1 \mathrm{~m})$ 当たり の基礎に対する地盤抵抗を表していて以下のようになる。

$$
{ }_{n} K^{e} S h \alpha=\sqrt{{ }_{n} K^{e} M^{e}\left(\tilde{\omega}_{1}^{2}-\omega^{2}\right)} \sqrt{1+\frac{M^{e}}{4_{n} K^{e}}\left(\tilde{\omega}_{1}^{2}-\omega^{2}\right)}
$$

上式の $\tilde{\omega}_{1}$ は側方地盤の 1 次固有円振動数を表していて、基礎に対 する加振実験の結果を踏まえ、既報の論文 ${ }^{1)}$ と同様、以下の值を採 用する。

$$
\tilde{\omega}_{1}=2 \pi f_{1}=7 \pi[\mathrm{rad} / \mathrm{sec}]
$$

つぎに、 $x$ 方向に伝播する地震動が各質点脚部に作用するときの 态答を求める。図 10 に示寸基礎一質点系モデルに対して、 $x$ 方向に 速度 $c$ で伝播する地震動を想定する。水平地動を $u_{g}(x, t)$ 、地動変位 振幅を $u_{0}$ とすれば、水平地動は次のように表現できる。

$$
u_{g}(x, t)=u_{0} e^{i \omega(t-x / c)}
$$

上式の地動が作用したときの $j$ 質点の応答を $X_{j}^{(2)} e^{i \omega t}$ と置けば、一

般質点の運動方程式は次のように表現できる。

$$
{ }_{n} K^{e} X_{j-1}^{(2)}+\left(2 K_{n}{ }^{e}+{ }_{s} K^{e}-M^{e} \omega^{2}\right) X_{j}^{(2)}-{ }_{n} K^{e} X_{j+1}^{(2)}={ }_{s} K^{e} U_{g j},
$$

$$
j=2,3, \cdots(5)
$$

ここで、

$$
U_{g j}=u_{0} e^{-i k x_{j}}
$$

上式の $k$ は波数で $k=\omega / c$ 。また、 $x_{j}$ は基礎中心から質点 $\mathrm{j}$ までの 水平距離を表し、基礎幅を $L$ 、質点間の間隔を $\Delta x$ とすれば、

$$
x_{j}=L / 2+\Delta x(j-1)
$$

さらに、質点 1 に関する連動方程式は以下のように表せる。

$$
\left(2_{n} K^{e}+{ }_{s} K^{e}-M^{e} \omega^{2}\right) X_{1}^{(2)}-2 K_{n} X_{2}^{(2)}={ }_{s} K^{e} U_{g 1}
$$

（5）式の差分方程式の一般解は次のように書ける。

$$
X_{j}^{(2)}=C_{R} u_{0}\left[A e^{-\alpha \cdot j}+e^{-i k\{L / 2+\Delta x(j-1)\}}\right]
$$

ここに、Aは積分定数で $(8)$ 式を満足するように定めれば、最終的 に以下の結果を得る。

$$
A=-i \frac{\sin k \Delta x}{\operatorname{Sh} \alpha} e^{(\alpha-i k L / 2)}
$$

また、（9）式の $C_{R}$ は次式で定義する。

$$
C_{R}=\frac{\tilde{\omega}_{1}^{2}}{\tilde{\omega}_{1}^{2}-\omega^{2}+\frac{2{ }_{n} K^{e}}{M^{e}}(1-\cos k \Delta x)}
$$

上式では ${ }_{s} K^{e} / M^{e}=\tilde{\omega}_{1}^{2}$ と置いている。

(9)式において $j=1$ と置けば、質点 1 の変位応答は以下のように なる。

$$
X_{1}^{(2)}=C_{R} u_{0} e^{-i k L / 2}\left[1-i \frac{\sin k \Delta x}{\operatorname{Sh} \alpha}\right]
$$

図 $10(\mathrm{a})$ に示す並列質点モデルに水平加振力と地震動が同時に作 用するときの質点 1 の変位応答 $X_{1} e^{i \omega t}$ は、(1) と (12)式の結果を加え て求めることが出来る。すなわち、

$$
X_{1}=C_{R} u_{0} e^{-i k L / 2}\left[1-i \frac{\sin k \Delta x}{\operatorname{Sh} \alpha}\right]+\frac{1}{{ }_{n} K^{e} S h \alpha} P_{R}^{e} .
$$

同様にして、図 10 (b) の基礎左方の側方地盤について考える。こ の並列質点モデルの端部質点に、水平加振力 $P_{L}^{e} e^{i \omega t}$ と (4) 式で表され る地動を受けるときの左側質点 1 の変位応答を $X_{-1} e^{i \omega t}$ とすれば、応 答振幅は最終的に次のように書ける。

$$
X_{-1}=C_{L} u_{0} e^{i k L / 2}\left[1+i \frac{\sin k \Delta x}{\operatorname{Sh} \alpha}\right]-\frac{1}{{ }_{n} K^{e} \operatorname{Sh} \alpha} P_{L}^{e}
$$

この式の $C_{L}$ は(11) 式の $C_{R}$ と同一である。

\section{3 基礎の応答解析}

基礎の振動モデルを図 10 に示す。この図に示すように、この基礎 は左右の側方地盤からの加振力と、基礎底面からは $\mathrm{x}$ 方向に伝播す る地震動の影響を同時に受けることになる。基礎に対する水平成分

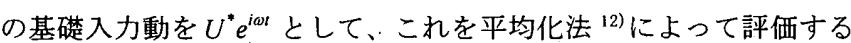
ことにすれば、基礎入力動は次式によって求めることができる。

$$
U^{*} e^{i \omega t}=\frac{1}{A} \int_{A} u_{g}(x, t) d A
$$

ここで、Aは基礎面積を表す。（4）式を(15)式に代入して積分すれ ば、

$$
U^{*}=\frac{\sin (k L / 2)}{k L / 2} u_{0}
$$

上式において、地震動の鉛直入射を想定すれば $c \rightarrow 0$ 、すなわち $k \rightarrow 0$ となるからこの場合の基礎入力動は $U^{*}=u_{0}$ となる。

（16）式の基礎入力動を受ける.基礎の運動方程式は、以下のように 表せる。

$$
\begin{gathered}
\left(\left[\begin{array}{cc}
K_{H} & \dot{1} \\
\cdot & K_{R} /\left(H^{e}\right)^{2}
\end{array}\right]-\omega^{2}\left[\begin{array}{cc}
M_{0} & h_{g} M_{0} / H^{e} \\
h_{g} M_{0} / H^{e} & J /\left(H^{e}\right)^{2}
\end{array}\right]\right)\left\{\begin{array}{c}
\Delta_{0} \\
H^{e} \Phi_{0}
\end{array}\right\} \\
=\omega^{2} M_{0}\left\{\begin{array}{c}
1 \\
h_{g} / H^{e}
\end{array}\right\} U^{*}-B\left[\begin{array}{cc}
1 & 1 \\
1 & 1
\end{array}\right]\left\{\begin{array}{c}
P_{R}^{e} \\
-P_{L}^{e}
\end{array}\right\}
\end{gathered}
$$

ここで、 $\Delta_{0}, \Phi_{0}$ 恃基礎底面での水平変位と回転角、 $h_{g}$ は基礎底面か ら基礎重心までの高さ、 $B$ は基礎幅 $(25 \mathrm{~m}) 、 H^{e}$ は並列質点モデル の等価質点高さ、 $M_{0}$ は基礎の質量、 $J$ は基礎底面における基礎の 慣性モーメントを表していて、基礎重心での慣性モーメントを $J_{0}$ と すれば次式で与えられる。

$$
J=J_{0}+h_{g}^{2} M_{0}
$$

一方、(13) 式と (14) 式の $X_{1}$ と $X_{-1}$ は並列質点もデルの等価質点高 さ位置での基礎の水平変位に等しい。すなわち、

$$
X_{1}=X_{-1}=\Delta_{0}+H^{e} \Phi_{0}+U^{*}
$$

（19）式を(13)と（14）式に代入して $P_{R}^{e}$ と $P_{L}^{e}$ の表現式を求めれば、 
$P_{R}^{e}={ }_{n} K^{e} S h \alpha\left(\Delta_{0}+H^{e} \Phi_{0}+U^{*}\right)-C_{n} K^{e} e^{-i k L / 2}(\operatorname{Sh} \alpha-i \sin k \Delta x) u_{0}$

$P_{L}^{e}=-{ }_{n} K^{e} \operatorname{Sh} \alpha\left(\Delta_{0}+H^{e} \Phi_{0}+U^{*}\right)+C_{n} K^{e} e^{i k L / 2}(\operatorname{Sh} \alpha+i \sin k \Delta x) u_{0}$

ここで、C=C$C_{R}=C_{L}$ 。

(20)式と (21) 式を(17)式に代入すれば、基礎の運動方程式は最 終的に以下のように表せる。

$\left(\left[\begin{array}{cc}K_{H}+2 \dot{K_{L}} & 2 K_{L} \\ 2 K_{L} & K_{R} /\left(H^{e}\right)^{2}+2 K_{L}\end{array}\right]-\omega^{2}\left[\begin{array}{cc}M_{0} & h_{g} M_{0} / H^{e} \\ h_{g} M_{0} / H^{e} & J /\left(H^{e}\right)^{2}\end{array}\right]\right)\left\{\begin{array}{c}\Delta_{0} \\ H^{e} \Phi_{0}\end{array}\right\}$

$$
\begin{aligned}
=\omega^{2} M_{0} & \left\{\begin{array}{c}
1 \\
h_{g} / H^{e}
\end{array}\right\} U^{*}-2 K_{L}\left\{\begin{array}{l}
1 \\
1
\end{array}\right\} U^{*} \\
& +2 C K_{L}\left(\cos k L / 2-\frac{\sin k L / 2 \sin k \Delta x}{\operatorname{Sh} \alpha}\right)\left\{\begin{array}{l}
1 \\
1
\end{array}\right\} u_{0}
\end{aligned}
$$

ここで、 $K_{H}$ と $K_{R}$ は図 10 の基礎底面に集約したスウェイとロッ キングの複素地盤ばねで実部と虚部から成る。これらの複素ばね は、基礎側方地盤以外の地盤剛性の影響を全て含んでいる。また、 $K_{L}$ は次式で定義していて、基礎側方地盤の複素ばねである。

$$
K_{L}=B_{n} K^{e} S h \alpha
$$

（22）式を解けば、地震動入射に対する基礎の応答を求めることが できる。さらに、それらの結果を(20)，(21) 式に代入すれば基礎の両 側面土圧が計算できる。ここで求まる地震時土圧は、単位幅の側面 土圧の合力である。これを単位面積当たりの土圧に直すためには既 報の論文 ゆの(33)式を用いて計算することになる。

\section{4 地震時土压に関する考察}

(20)式と (21) 式を元にして、定常状態における地震時土圧の計算 式を改めて書けば(24)，(25) 式のように整理できる。なお、地盤の圧 縮匤力を正土圧としている。 $P_{R}^{e}={ }_{n} K^{e} \operatorname{Sh} \alpha\left(\Delta_{0}+H^{e} \Phi_{0}+U^{*}\right)-C_{n} K^{e} \operatorname{Sh} \alpha\left(\cos k L / 2-\frac{\sin k L / 2 \sin k \Delta x}{S h \alpha}\right) u_{0}$

$$
+i C_{n} K^{e} \operatorname{Sh} \alpha\left(\sin k L / 2+\frac{\cos k L / 2 \sin k \Delta x}{\operatorname{Sh} \alpha}\right) u_{0}
$$

$$
\begin{aligned}
P_{L}^{e}=-{ }_{n} K^{e} \operatorname{Sh} \alpha\left(\Delta_{0}\right. & \left.+H^{e} \Phi_{0}+U^{*}\right)+C_{n} K^{e} \operatorname{Sh} \alpha\left(\cos k L / 2-\frac{\sin k L / 2 \sin k \Delta x}{\operatorname{Sh} \alpha}\right) u_{0} \\
& +i C_{n} K^{e} \operatorname{Sh} \alpha\left(\sin k L / 2+\frac{\cos k L / 2 \sin k \Delta x}{\operatorname{Sh} \alpha}\right) u_{0}
\end{aligned}
$$

（24）、（25）式の右辺第 1 項は、基礎の水平動に対して地盤が抵抗 する際に発生する側面土圧で、左右の基礎側面には逆位相の土圧を 発生させる。また、これらの式の第 2 項と第 3 項は、地震時に基礎 側方地盤が基礎に対して作用する側面土圧を表している。さらに、 第 2 項は基礎側方地盤が同一方向に震動する際に発生する土圧を、 第 3 項は左右の側方地盤の一方が右方向のときに他方が左にという ように、互いに逆方向に震動する際の土圧である。当然のことなが ら、第 2 項は左右の基礎側面に逆位相の土圧を、第 3 項は同位相の 土圧を発生させることになる。したがって、第 2 項は基礎に対する 地震入力として有効に作用するが、第 3 項は左右側面で土圧が相殺 されるため、基礎に対しては有効な入力とはならない。これが、(22) 式の第 2 項は (24)、(25) 式の右辺に登場するが、第 3 項が含まれて

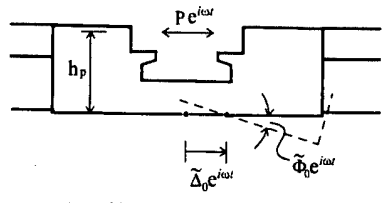

（a）基歪に対する加振実梌

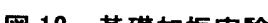

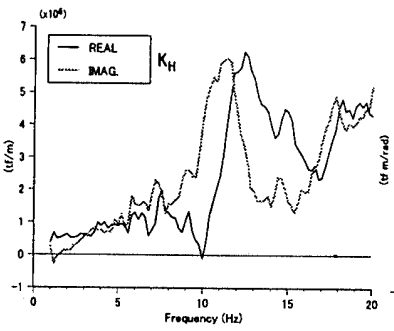

(a)スウェイばね

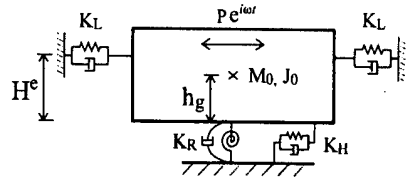

(b) 地盤抵抗のモデル

\section{図 13 基砋底面の裸素ばね}

いない理由である。さらに、地震動が鉛直入射する場合には $c \rightarrow \infty$ と置けるから、波数 $k$ は $k \rightarrow 0$ となる。このため、(24)、(25) 式の 右辺第 3 項は 0 となり、相対する基礎側面には同位相の土圧は発生 しないことになる。

基礎側面の地震時土圧を評価する場合、基礎の水平動に対して地 盤が抵抗する際に発生する土圧（地震時受働土圧）と、基礎側方の 地盤震動が基礎におよぼす土圧（地震時主働土圧）に分離する考え 方もある。この考え方によれば、（24）、（25）式の右辺第 1 項は、基 礎の水平動に対する地盤抵抗を表していて、受働土圧成分となる。 また、第 2 項と第 3 項は基礎側方地盤の震動に対して発生する土圧. を表しており、主働土圧成分となる。さらに、上で考察した土圧の 発生機構の分析によれば、主働土圧には基礎に対して有効な入力と なる逆位相成分と、相対する基礎側面で互いに相殺する同位相成分 が存在することになり、両者を区別して評価することが重要となる。 先に、高振動数成分が卓越するグループCでは、基礎側面土圧は 基礎の加速度応答と対応していることを述べたが、この現象は(24)、 （25）式をもとに以下のように考察される。すなわち、(2)、(11)式か ら分かるように、 $\omega \rightarrow \infty$ の時、

$$
{ }_{n} K^{e} \operatorname{Sh} \alpha \rightarrow M^{e} \omega^{2}, \quad C_{n} K^{e} \operatorname{Sh} \alpha \rightarrow \text { const. }
$$

となる。したがって、 $\omega \rightarrow \infty$ の時、(24)、(25)式右辺にある三つの 項の中で第 1 項が優勢となり、この項は基礎の慣性力と等価になる のが分かる。同時に、高振動数域では相対する基䃈側面土圧が逆位 相で発生することも説明できる。

最後に、 $\omega \rightarrow 0$ すなわち静的な状態での基礎側面土圧について考 察しておこう。この場合には、(11) 式より $C_{R}(=C) \rightarrow 1$ 、また (2) 式 より ${ }_{n} K^{e} S h \alpha \rightarrow$ const. となり、さらに $k \rightarrow 0$ となるから、基礎側面土 圧の表現式は以下のようになる。

$$
P_{R}^{e} \propto\left(\Delta_{0}+H^{e} \Phi_{0}+U^{*}-u_{0}\right), \quad P_{R}^{e} \propto-\left(\Delta_{0}+H^{e} \Phi_{0}+U^{*}-u_{0}\right)
$$

したがって、振動数がごく小さい場合には、基礎側面土圧は基礎 の変位応答と地盤変位との差に比例して発生し、基礎の左右の側面 土圧は逆位相で発生すると推定される。このことは直感とも矛盾し 
ない。ただし、本観測記録からは静的に近 い状態での土圧特性は抽出できていない。

\section{5. 地畲時土压の解析と舅測值との比较 5.1 数值解析の基本方針}

（1）基礎底面集約複素ばねの算定

（22）式を用いて基礎の地震応答を計算 するためには、 $K_{H}$ と $K_{R}$ を予め求めておく 必要がある。本論文では、既報の論文 ${ }^{1)}$ 詳述した基礎の加振実験結果 (100gal 加振 実験)をもとに、以下の手順でこれらの值を 評価した。

まず、図 12 (a)に示すように、振動台基礎に水平加振力 $P e^{i \omega t}$ が作 用したときの基礎底面での水平変位と回転角を算出し、それらを $\tilde{\Delta}_{0} e^{i \omega t}, \tilde{\Phi}_{0} e^{i \omega t}$ とする。一方、図 12 (b) は図 (a) と等価な簡易モデルを 表していて、モデルの基礎底面には $K_{H}$ と $K_{R}$ のスウェイとロッキン グの複素ばねを、基礎側方には側方地盤抵抗を表現する $K_{L}$ の複素 ばねが配してある。図 12 (a) と（b)に対して、加振力に対する基礎底 面の変位と回転角が両者で等しくなるように $K_{H}$ と $K_{R}$ を定めるの が合理的である。この考え方に基づいて $K_{H}$ と $K_{R}$ の算定式を導けば、 最終的に以下のようになる。

$$
\begin{aligned}
& K_{H}=\frac{1}{\tilde{\Delta}_{0}}\left[P+M_{0} \omega^{2}\left(\tilde{\Delta}_{0}+h_{g} \tilde{\Phi}_{0}\right)-2\left(\tilde{\Delta}_{0}+H^{e} \tilde{\Phi}_{0}\right) K_{L}\right] \\
& \left.K_{R}=\frac{1}{\tilde{\Phi}_{0}}\left[P h_{p}+M_{0} \omega^{2} h_{g} \tilde{\Delta}_{0}+J \omega^{2} \tilde{\Phi}_{0}-2\left(\tilde{\Delta}_{0}+H^{e} \tilde{\Phi}_{0}\right) H^{e} K_{L}\right] （ 27\right) \\
& \text { ここに、, } h_{p} \text { は基礎底面から水平加振力の作用高さ }(7.2 \mathrm{~m}) \text { を表す。 }
\end{aligned}
$$

他の記号は (17) 式と (23) 式で定義した通りである。図 13(a)、(b)に は(26)、（27）式に基づいて計算した $K_{H}$ と $K_{R}$ の結果が示してある。

図 13 より、 $K_{H}$ と $K_{R}$ は $7 \sim 10 \mathrm{~Hz}$ 以上の高振動数域では実部、虚 部ともに急激に変動し、振動数に対する依存性が強くなっている。 この理由の一つは、この振動台基礎は、ほぼ $10 \mathrm{~Hz}$ 以上の高振動数域 では基礎ピット部の曲げ変形が顕著となり ${ }^{2)}$ 、低振動数域における 剛体挙動とは大きく変わることが考えられる。

（2）地震波の伝播速度の仮定

(22) 式および(20)、（21）式を利用して基礎の地震応答と地震時土 圧を計算するに当たっては、地震波の伝播速度 $c$ を決定する必要が ある。この伝播速度は地盤構造や地震波の入射角度に関連するもの で、地震毎、あるいは時間の経過に伴って変化するものであろう。 残念ながら、この值は観測からは求められないため、数值を仮定す ることになる。本論文では地震動の伝播速度を $c=3,000 \sim 100,000 \mathrm{~m} / \mathrm{sec}$ の籁囲で種々変化させ、計算值と観測值と の比較を試みた。以下には、それらの中から観測値との対応が比較 的良好であった $c=10,000 \mathrm{~m} / \mathrm{sec}$ の結果と比較してある。

\section{（3）基礎底面深さでの地震動の計算}

基礎の地震応答と地震時土圧を計算し、それらを観測値と比較す るためには、基礎及び側方地盤に入力として作用させる地震動の時 刻歷波形を求める必要がある。振動台基礎が支持されている $-8 \mathrm{~m}$ での自由地盤の地震動は直接観測されていない。そこで、自由地盤

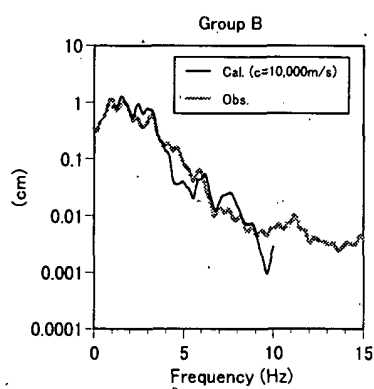

(b) Group B

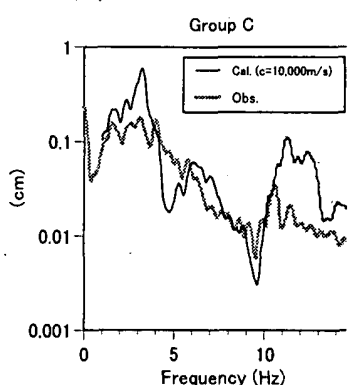

(c) Group C
图 14 基碐速度応答の钚测値と計算結果の比較
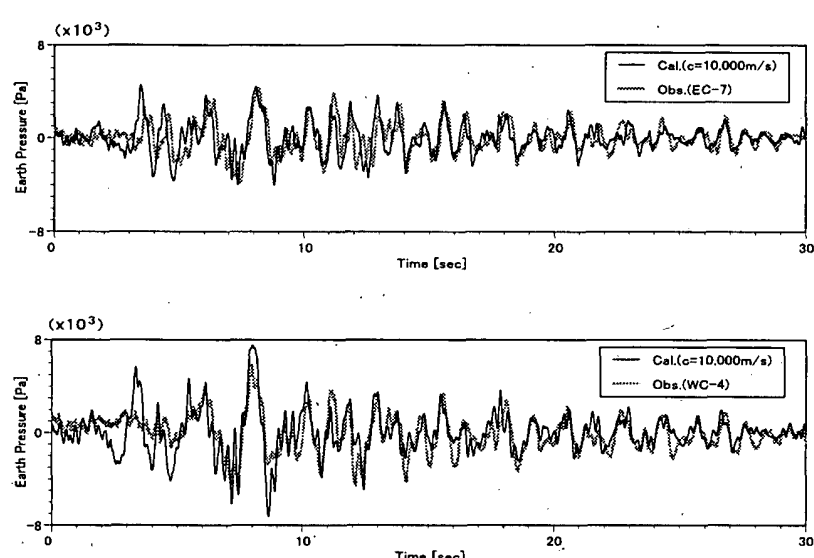

(a) Group $A$
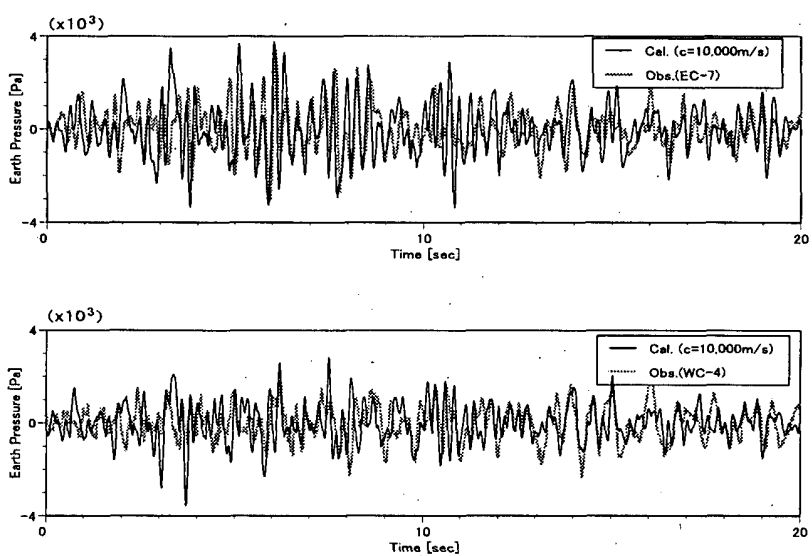

(b) Group B
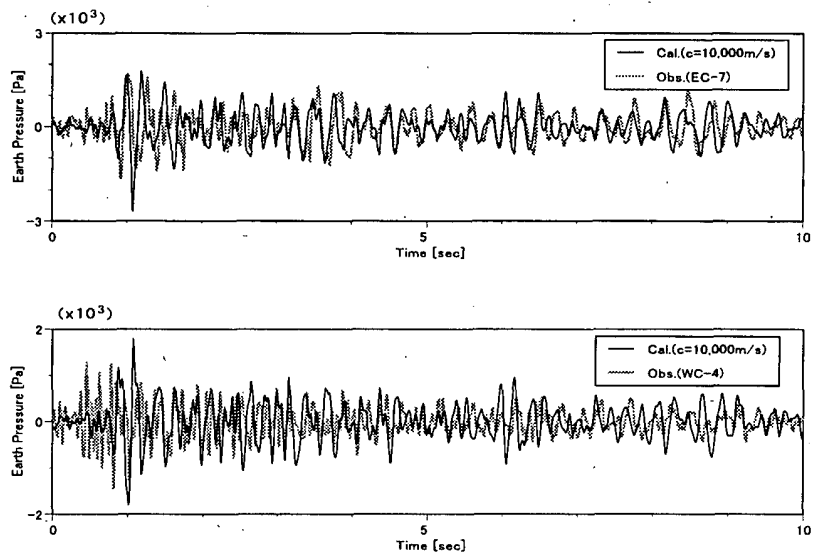

(c) Group C

图 15 土圧波形の镂測値と㖕算結果の比較 
の地中ー $40 \mathrm{~m}$ とー $1 \mathrm{~m}$ の地震動記録を元にして、既論文 ${ }^{3)} に$ 示した方 法を用いて $-8 \mathrm{~m}$ での地震動の時刻歴波形を数值計算によって求め た。計算法の詳細は文献 3)を参照願うことにして主要な計算条件を 以下に記しておく。

1）地盤構造は最下層を半無限地盤とする 7 層の平行成層地盤と し、Thomson-Haskell の方法を用いて計算した。なお、この自由地 盤の地震動解析では、地震波の鈆直入射を仮定した。

2 ）地盤は履歷型の粘弾性体として、地盤の減衰定数 $h$ を次式よ り定めた。ただし、下式の $\omega$ は円振動数である。

$h=\alpha / \omega+\beta, \quad\left(\alpha=1.0 \mathrm{sec}^{-1}, \beta=0.02\right)$

$3 ）$ NS、EW 方向に対して記録された地震動記録を基礎の長辺方向 に変換し、得られた波形を基礎一地盤系モデルに対する入力地震動 とした。

なお、上述の係数 $\alpha, \beta$ は- $1 \mathrm{~m}$ と $-40 \mathrm{~m}$ で観測された地震動記録 をもとに同定して得たもので ${ }^{3)}$ 、各層同一とした。また、この地盤 の $40 \mathrm{~m}$ までの 1 次の固有振動数は約 $1.5 \mathrm{~Hz}$ であり、これに対态する 地盤の減衰定数は $h \approx 0.13$ となる。この值は、基碟側方地盤に対し て想定した減衰定数 $(h=0.1)$ とほぼ同一の値となる。

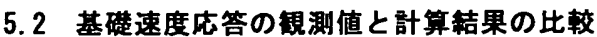

前述の方法により求まる基礎底面媣さでの自由地盤地震動を、図 10 の基礎一地盤系モデルの入力地震動として作用させ、基礎の地震 応答解析を行なった。比較は、各グループに対して $c=10,000 \mathrm{~m} / \mathrm{sec}$ として計算した基礎速度応答と、観測点 S3 で記録された加速度記録 を積分して求めた速度応答の観測值について行なった。図 14 (a)〜 （c）には、基礎速度応答の振幅スペクトルが比較してある。計算で考 虑した振動数範囲はグループ A, B では 1 10Hz、高振動数成分を多 く含むグループCでは $1 \sim 15 \mathrm{~Hz}$ である。これらの結果より、グルー プ A, B については観測値と計算值は比較的良く一致していると言え る。これに対して、グループCでは両者の対応はグループ A, B に比 して劣るが、全体の傾向は両者良く一致している。

\section{3 地震時土压波形の铸测值と計算結果の比较}

図 $15(\mathrm{a}) \sim(\mathrm{c})$ には、グループ毎の地震時土圧波形の観測值と $c=10,000 \mathrm{~m} / \mathrm{sec}$ として得た計算結果が比較してある。この伝播速度 は、長さ $39 \mathrm{~m}$ 離れた振動台基礎の両側面に作用する地震動に $0.0039 \mathrm{sec}$ の時間差が生じていることを意味している。

これらの結果に見るように、グループ A, B については観測值と計 算結果は良く一致していて、特にグループAの対応が良い。一方、 グループ C に関しては両者の対応はグループ A, B に比して劣るが全 体的に見て良く一致していると言えよう。このことから、本論文で 提示した簡易モデルは、地震時土圧の定性的・定量的評洒に利用で きると考える。

\section{6. むすび}

本論文では、大型振動台基礎側面で観測された地震時土圧を分析 して、土圧特性を抽出すると共に、質点一ばねーダッシュポットか ら成る簡易な基礎一地盤系モデルによる地震時土圧の数值解析を行 い、観測值との比較を試みた。本論文で得られた主な知見をまとめ ると以下のようになる。

（1）観測された地震動記録を、波形に含まれる振動数成分に応じて 3 つのグループ（グループ A, B, C）に分類し、振動数と基礎側
面土圧の関係について検討を行った。その結果、基礎側面の土 圧性状は地震動に含まれる振動数成分によって大きく異なる ことを示した。

（2）グループ毎に相対する基礎側面土圧の位相関係、さらには基礎 応答と側面土圧との関係を検討した結果、全体の傾向はおおよ そ以下の表のようにまとめることが出来る。

\begin{tabular}{|c|c|c|}
\hline Group & 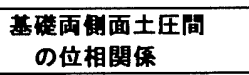 & 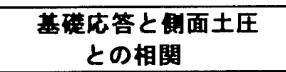 \\
\hline A & $\begin{array}{l}\text { 初期微動 : 逆位相. } \\
\text { 全般に同位相. }\end{array}$ & 速度応答と強い相関. \\
\hline $\mathrm{B}$ & $\begin{array}{l}\text { 初期微動：逆位相. } \\
\text { 主要動以降：同位相. }\end{array}$ & $\begin{array}{l}\text { 速度応答と相関有り. } \\
\text { 一部、加速度応答と相関. }\end{array}$ \\
\hline $\mathrm{C}$ & 全般に逆位相. & 加速度応答と強い相関. \\
\hline
\end{tabular}

（3）本論文で提示した簡易な基礎一地盤系モデルを用いて行った 地震時土圧の解析結果は、比較的低振動数成分を含む地震動に ついては、観測值と良く一致した。また、高振動数成分を含む 地震動に対しても、解析結果は観測值とおおむね良好な対応を 示した。この事より、提示した簡易な基礎一地盤系モデルは地 震時土圧の定性的・定量的評価の一手法として利用できる。

\section{参考文献}

1) 井口道雄,佐土平敦美, 箕輪親宏 : 加振実験時の大型振動台基礎側面に作 用する動土圧の観測と解析、日本建築学会構造系論文報告集、第 549 号、 pp.75-82、2001年11月

2) 箕輪親宏,大八木規夫,小川信行,大谷圭一 : 大型耐震実験装置基礎補強工 事（補強工事の概要と基礎振動応答測定）、防災科学技術研究所研究資 料、第 151 号、1991 年 3 月.

3）井口道雄,宇波挑子,安井 譲, 簧輪親宏 : 大型振動台基礎と周辺地盤の 同時地震観測に基づく基礎有効入力動、日本建築学会構造系論文報告集、 第 537 号、pp.61-68、2000 年 11 月

4) Iguchi, M., Y. Yasui and C. Minowa: On Effective Input Motions: Observations and Simulation Analyses, Proc. of the Second U.S.-Japan Workshop on Soil-Structure Interaction, Building Research Institute, Ministry of Land, Infrastructure and Transport of Japan, pp75-87, March, 2001.

5) 小淵康義,海津信廣：LNG 地下式貯槽の地震時挙動について、第 20 回地 震工学研究発表会講演梗概、pp.517-521、1989 年.

6) 藤森健史 : 地震時土圧波形による建築構造物への入力地震動評価に関す る研究、学位論文 (東北大学)、1993 年 12 月.

7) 内山正次,山下利夫 : 哚く埋込まれた構造物の地震時側面士圧の挙動に 関する研究、日本建築学会構造系論文報告集、第 516 号、pp.105-112、 1999 年 2 月.

8) 境 茂樹, 増田 彰, 今村 晃, 岸野泰章, 石井 寿,四ツ田裕呞,井上 超 : 深首地下構造物に作用する地震時の動的士圧分布一その 3 : 地震時 変動側圧記録の解析一、日本建築学会大会学術講演梗概集（近幾）、 pp.417-418、1996 年 9 月.

9) 松本尚志,有泉幸蔵, 国吉秀城, 千葉 脩, 渡壁守正: 深い根入れを有する建 築物の地震観測、第 8 回日本地震工学シンポジウム、pp.1035-1040、1990 年.

10）鬼丸貞友,菅原良次,植竹富一,杉本三千雄,大宮幸男 : 高密度地震観測に基 つく地震時土圧の研究、第 9 回日本地震工学シンポジウム、pp.1051-1056、 1994 年.

11）風間基樹,稲富隆昌：ケーソンに作用する地震時動土圧に関する模型振 動実験、土木学会論文集、第 416 号、pp.1-13、1990 年 4 月.

12）日本建築学会編：入門・建物と地盤との動的相互作用、日本建築学会、 1999 年 4 月. 